\title{
Risks of Adopting Automated AIS Applications on the Quality of Internal Auditing
}

\author{
ADEL M. QATAWNEH \\ Associate Professor of Accounting \\ Faculty of Business \\ Al-Zaytoonah University of Jordan \\ JORDAN
}

\begin{abstract}
The current study aimed at examining the impact of AIS risks (IT Infrastructure ,Data Entry and Outcome, Internal Operations, Control procedures and tools and Data Security) on quality on internal auditing as a comparison study between Jordan and England. Study adopted quantitative approach and istributed a questionnaire on (133) internal auditors in Jordan and (331) internal auditors in England. Through SPSS results of study indicated that all adopted risks were found within both samples responded tb questionnaire. Both sample also indicated that "internal operations" and "data security" are the most influential risks that may jeopardize quality of internal auditing. Results also indicated differences between impacts of such risks on quality of internal auditing; such risks were attributed to the large population of England compared to Jordan and the intensity of internal auditing in England as higher than Jordan due to the intensity of operations within the country. However, "IT infrastructure" and "data security" appeared to be higher in England compared to Jordan which helped in easing the negative impacts of AIS risks on quality of internal auditing. Study recommended applying restrictions on users to limit the possibility of changing and manipulating data whether by parties inside or outside the organization, in addition to presenting extra efforts in choosing internal auditors in terms of qualifications, experiences and abilities.
\end{abstract}

Keywords:- Automated AIS, Reliability, Internal auditing, Fraud, Electronic Piracy, Data Entry, Unauthorized Use, Entry Errors, Data, Information, IT, Computerized

Received: October 15, 2020. Revised: April 3, 2021. Accepted: April 15, 2021. Published: April 21, 2021.

\section{Introduction}

The accounting information presented by accounting department in an organization must be of a high level of quality in terms of the qualitative characteristics of data and information, this is very important to ensure the rights of stakeholders to take the required decisions according to the needs of the organization [35]; [48]. The same thing, noting that accounting information is one of the most important elements of organizational production and has a major role in determining the efficiency of the organization and mechanism of dealing with the data flowing in it. From here, many advanced accounting systems have emerged, which actually aimed to control the huge amount of data flowing within the organization, process it and ensure that it reaches all administrative levels in an appropriate and timely manner in order to use it in taking rational decisions [40]. With the scientific and technological development in the business environment, organizations are making every effort to access the world's latest technologies, applications and advanced technological tools that help the organization enter the globalization world in an easy, smooth and flexible way [25]. Some relevant studies can be found in [19] and [37] which indicated that many organizations oriented themselves to computerize their accounting practices as a way to shorten the time and effort in carrying out accounting activities, ensure a high quality accounting results and organize the flow of accounting information. [31] and [28] emphasized that gathering between technology and accounting practices has prompted the Institute of Internal Auditors (IIA) to adopt a new combination of internal audit capable of harmonizing with the requirements of current technological development as "an independent and purposeful assurance advisory activity or function created by organizations to improve their operations and add value and assists it in achieving its goals through a 
specific and clear approach to evaluate and improve the effectiveness of operations, control and direction" [34]. As far as researcher knows, quantity of research on relationship between AIS applications and internal auditing didn't get that much attention and the research which gathered between the two variables seemed to be scarce and not direct. From that point, it was a little challenging to go through this relationship from the perspective of previous studies; researcher built the problem on the bases of employing tech tools and internet along with the idea of "influencing quality of internal auditing". In addition to that, COVID19 was a big obstacle in achieving main aim of study, basically it was preferred that the method it better to be qualitative through meetings with auditors, gain qualitative data from them and compare and contrast with the two samples. However, it appeared that the only option - with OVID 19 and the worldwide lockdown - is to follow the qualitative approach and gain numerical data remotely due to lockdown in which auditors weren't found in their offices and worked also remotely. Current study contributed in shedding the light on the fact that no matter how helpful, useful, supporting and manageable AIS applications can be, there still a space for error and faults which are accompanied by the employment of tech tools and computerized systems on auditing and accounting practices, this can be attributed to piracy, hacking, system failures and unauthorized entry to sensitive data and files and manipulate their content.

\section{Problem Formulation}

Based on above argument; current study aimed at examining the risks emerging from utilizing automated AIS on quality of internal audit among internal auditors in Jordan and England and compare results between the two environments of Jordan and England. Reaching this aim was planned through achieving following objectives:

- Identify the concept of AIS application within organizational environment

- Highlight the risks associated with AIS applications

- Draw the relationship between AIS applications and internal audit quality

- Compare and contrast between AIS applications' risks in Jordan and England as according to statistical results reached by the current study.

Generally speaking, current study seeks to answer the following question: Do AIS applications have foundations that prevent risks and raise the level of internal audit outputs? In order to achieve above aim, researcher built the following model to identify the relationship between variables of study which were retrieved from [7] and [5].

\section{Independent Variables}

Dependent Variables

\section{Risks of Automated AIS Application}

IT Infrastructure

\section{Data Entry and Outcome Internal Operations}

Control procedures and tools

Data Security 
From figure above, following set of hypotheses was extracted:

\section{H1: Risks of AIS Application has an influence on the Quality of Internal Auditing}

H2: The impact of Risks of AIS Application on increasing Quality of Internal Auditing differs between Jordan and United Kingdom

\section{Literature Review and Hypotheses Development}

\subsection{Accounting Information Systems (AIS)}

It is well known that a system usually consists of a group of elements which interconnectedness leads to the completion of a specific function [13]. Whether the system is computerized or not, it is usually governed by a set of principles, standards, controls and provisions that must be followed routinely in order to ensure the best outputs [11]. Accounting - like all other fields - has its own regulations, applications, standards and provisions that mustn't be violated. Accounting information system (AIS) was defined as systems whose responsibility is to provide financial and statistical reports based on high quality foundations, in terms of inputs, processes and outputs that help in the decision-making process of a managerial or financial nature [16]. From another perspective, AIS is a group of systems concerned with financial reports related to the organization, whether in the internal or external environment, and its function is to process data on financial transactions and present them to specific departments [45]. The nature of the outputs of AIS varies according to the nature and size of the organization, the amount of data flowing, and nature of organizational operations [9]. Based on that, the application, usage, employment and usefulness of AIS application in all its forms differs greatly from one environment to another, this included organizational environment, expertise of auditors, and regulations followed within the organization. On a bigger level, the application, usage, employment and usefulness of AIS application differs in terms of a country, it can't be said that employing AIS applications in Germany is the same as its application in Netherlands, the size, population, operations and governance in each country differs which also throws its difference on the way AIS applications are used.

\subsection{Automated Accounting Information Systems}

The idea of adopting a specific system in the internal or external operations of an organization is based on one basic goal, which is to provide the concerned authorities with appropriate information at the right time; the success of such systems is connected to its ability to achieve the goal and provide correct and reliable information when needed [22]. Consequently, the organizations' continuous pursuit aims to adopt sophisticated and complex systems so that they are able to present accurate, reliable and relevant information in order to adopt it and thus build correct and informed decisions based on it [47]. This continuous pursuit has led to the emergence of automated AIS applications, which was defined by [3] as a group of systems that employ individuals, electronic software and information in order to enter and retrieve raw data in the form of information that serves the target parties and helps them to carry out their main activities. Automated AIS is utilizing computer and technological applications in order to deal with the financial data of the organization like classification, processing and presentation of information that is understandable, accurate, clear and relevant to the beneficiaries [20]. It indicated that the idea of automated AIS applications received a lot of welcome as it represented an approach to avoid human errors resulting from manual work, in addition to reducing the time and effort required to access information that might have needed a lot of time in the past [15]. 


\subsection{Risks Associated with Automated AIS Applications}

Logic requires that computerized AIS be one of the most vulnerable systems due to their dependence on computers and networks, which would affect the achievement of these systems 'goals, objectives and outputs [14]. T the great technological development and use of Internet that accompanied the development of these systems has created many risks represented in information security, failure to provide outputs, disruption of accounting services in the facility and many material and moral losses that accompany these risks [6]. The issue of the risks to which automated AIS applications may be exposed to is one of the hot topics that are now invading the world of research due to the continuing technological development associated with many programs related to piracy through the Internet in addition to the phenomenon of the Dark Web, which is used by others in a manner aimed at achieving embezzlement, theft and electronic piracy [42]. Much of the previous research has dealt with - [23], [43], [27] and [33] - the idea of automated AIS applications' risks, their forms and dimensions, and the identification of the risks that can direct these systems, in addition to the mechanism of their impact on the organization in general and on its performance particularly financial. The study [26] is one of the first studies that dealt with the idea of automated AIS risks, where researchers conducted a survey distributed on (657) managers of information systems in the United States of America and showing the extent of their awareness of the security and non-security risks associated with automated AIS. On this topic, many risks which included technological infrastructure, internal and external environment of the organization, intended and unintended errors of the personnel working with the applications and entries and commands given to them, as well as the researchers added other risks including natural disasters and electronic piracy.

In identifying the most important risks that threaten information security in automated AIS within Saudi organizations, the study showed that the participating organizations had suffered many financial losses associated with information security risks and accountability, which led to embezzlement, fraud and infringements of information security which were discovered by accident. It was pointed out that the existence of this type of risk is due to mechanism for entering data - whether it was intended or unintended errors -, technological infrastructure, as well as the use by individuals who are not authorized to view, print and display the information [2]. It was indicated that there are many risks which could be associated with employing automated AIS in the organization; such risks would have a strong impact on financial and managerial performance of the organization including technological infrastructure and the extent of its strength in dealing with viruses which could reach the accounting system [46]. Individuals are considered to be a risk in terms of accessing systems, the use of passwords, obliterating or destroying the outputs of the system, or cases of unauthorized disclosure of data and information by displaying or printing them. I indicated that there are many risks related to the use of automated AIS, but the most frequent of them was the unintended or intentional entry of wrong data by working personnel, as well as the intended or unintended destruction of the data already in the system by individuals working within the organization, this resembles the risks of data entry [30].

\subsection{Internal auditing}

The concept of internal auditing is one of the managerial and financial tools that are utilized to organize financial and managerial issues such as decisions, plans, and strategies, thus ensuring that the desired goals are reached [31]. Internal audit is defined as a type of managerial control that aims to evaluate other control tools in the organization and thus assist managers at all levels in making sound and informed decisions [34]. Organizations have aimed to develop the performance of internal auditors in the hope of achieving high-quality internal auditing by following managerial and financial approaches and methods that ensure that the organization reaches a high stage of quality in internal audit [20]; [32]. The internal audit focuses on identifying, examining and reviewing financial 
and managerial information and demonstrating its conformity with reality, in addition to reviewing its reliability and classification and submitting reports representing this information [21]. It is among the tasks of internal auditing to evaluate and review the accounting system in the organization and assess efficiency of the accounting systems used in order to ensure the highest level of accuracy and appropriateness of financial data and reports related to the organization's conditions as was also agreed on by [17]; [39].

\subsection{Quality Internal Auditing}

Based on the fact that quality is the extent of conformity with requirements, and the organizations that seek to reach the level of quality are actually organizations that try to monitor their daily activities and work, reduce errors, detect deviations and serve the top management in the best possible way, then the quality of internal audit refers to providing a high-quality internal audit by matching the accounting system that was adopted with realistic figures and data, and then ensuring access to the required effectiveness and efficiency [31]. The quality of internal audit is the ability to identify weaknesses and strengths in internal auditing and to present all proposals and recommendations to address weaknesses and exploit strengths [24]. As for [8] it was found that the quality of internal audit is nothing but the great commitment in the internal audit standards and professional codes of conduct during the practice of the audit activity.

\subsection{Standards of Quality Internal Auditing}

It indicated that there are many factors that determine the quality of internal audit. In principle, the auditing standards (65) which were issued by the AICPA in 1991 indicated that qualification and experience are among the most important criteria for the quality of internal audit, it included practical qualification, experiences, courses and the professional certificates of the internal auditors, in addition to the competence of the body that appoints these auditors [10]. As for [29], it was indicated that the IIA in 2003 introduced standards for the quality of internal auditing that included independence, objectivity, and professionalism. Quality of internal auditing is of great importance as it highlights the overall performance of the organization and makes a good source to take informed decisions [4]; [49]. For that reason, there are standards for quality internal auditing which were mentioned by [12], [31] and [18] and included:

\section{Qualification}

Qualifications refer to the knowledge, experiences, personal characteristics, understanding and methods of the internal auditor, in addition to the methodology used in auditing and other competencies required of him, such as university degree and training. These matters greatly contribute to affecting the quality of internal audit, as the internal auditor must have a degree in accounting, auditing, financial, legal and business fields or any other specialization appropriate to the nature of the job required of the internal auditors.

\section{Independence}

Independence here refers to the independence and isolation of the auditor from the activities that he audits in order to ensure transparency in the work in addition to freedom and objectivity in the results. The meaning of the internal auditor being independent is that they perform their work and give neutral results freely and objectively without any external or internal pressures present within themselves. Independence has a great impact on the quality of internal audit, as it contributes significantly to improving the audit process and giving it an individual status and objectivity.

\section{Proficiency and professional care}

Professional competence in internal audit is one of the most important factors in giving high-quality internal audit results, as professional competence combines independence with the addition of knowledge, skills and specializations necessary for the advancement of the audit function. Professional competence in internal auditing, its procedures and methods, is essential in the performance of audits 
as they involve applying knowledge in the situations faced by the auditor and dealing with them without the excessive use of technical assistance and research.

\section{Scope of work}

The scope of work standard in internal auditing refers to examining and evaluating the efficiency and effectiveness of the concerned organization, and this includes auditing the risk management strategies, the governance adopted in the organization in addition to the internal controls and the extent of compliance with them and the quality of performance while carrying out the responsibilities assigned to individuals.

\section{Perform auditing tasks}

As for the performance of auditing work, it is the fifth criterion for the quality of internal audit and it refers to the work of examination, evaluation, follow-up, planning and implementation of internal audit work, for which the auditor is usually responsible.

\section{Managing the internal audit function}

The sixth criterion for the quality of internal auditing is the management of the audit entity, which is one of the tasks of the first audit official and is duly done by ensuring that the audit work is carried out as required and the internal audit resources are used efficiently and effectively so that the audit work matches the internal audit standards.

\subsection{Influence of Automated AIS Applications on Internal Auditing Quality}

Automated or computerized AIS involve many risks that contribute effectively to exposing the internal audit to a loss of credibility, validity and conformity with reality, and this is what [7] indicated to him when he confirmed that and among the risks of computerized accounting information systems is the idea of the possibility of storing a huge amount of data in it, and here it is difficult for the organization to make hard copies of this huge amount of data due to its huge size and the difficulty of storing and maintaining it.

On the other hand, one of the risks of automated AIS and their impact on internal auditing - [5] - is the idea that it is difficult to discover errors related to inputs, or even in the information system itself, and therefore the internal auditor is forced to deal with the stored data as it is and rely on its results [36]. And its reports that appear as outputs of the inputs, whether they are correct or tampered with, that is, the changes and manipulations that may take place on the stored data cannot be detected or any tampering or change in it can be detected. It was emphasized that among the risks of computerized accounting information systems is the difficulty of retracting the steps that the internal auditor takes, meaning that the step that he takes can only correct them by re-checking completely, so the change in the steps followed or avoiding mistakes and correcting them is very difficult in computing systems compared to manual systems [30]. One of the risks, which is passive exploitation, that is, the exploitation of system information and data by individuals who are not authorized to access the system or those individuals who are called to develop the system, this matter is capable of destroying the organization by leaking its information and data to competitors [44].

Among the most important and greatest risks of accounting information systems is the idea of complete destruction of the existing data and records entered by the organization, and thus the organization may suffer a complete loss of its data between day and night [41].

The idea of this regulator's association with an electronic network makes the idea of controlling it somewhat difficult and therefore the competent departments cannot carry out the necessary monitoring of networks and systems due to the difficulty of this, especially with its automation [38]. 


\section{Methods}

\section{Methodological Approach}

Current study aimed at collecting data that are able to explain the nature of influence that automated AIS applications has on the quality of internal auditing. For this reason, and due to COVID 19 precautions in addition to the comparison held between countries in different geographical locations (Jordan and England); researcher was only able to adopt the quantitative approach through depending on numerical data. Achieving this aim was done through utilizing a questionnaire as a tool of study; the questionnaire consisted of two main sections, the first included demographics of study sample while the other section included variables of study including (IT Infrastructure, Data Entry and Outcome, Internal Operations, Control procedures and tools and Data Security). Questionnaire was presented on liker 5 scale were 1 strongly disagree, 2 disagree, 3 neutral, 4 agree, 5 strongly agree.

Population and Sampling
Population of study consisted of all auditors within both Jordan and England, due to the impossibility of gathering all auditors in the two countries; researcher took a convenient sample which can be reached online and through emails. Initially, the sample included Jordan (150) auditors and England (400) auditors from auditing offices within the countries. The questionnaire was uploaded online 'Google Forms' in order for both sample from Jordan and England to have access to it. Application process was done over a period of (15) days, after that, researcher was able to retrieve (133) properly filled questionnaire from Jordanian sample which indicated a response rate from Jordan (88.6\%) and England presented (331) properly filled questionnaires which gave a ratio of $(82.7 \%)$ as statistically acceptable.

Screening and Analysis of Primary Data

SPSS was used in order to screen and process gathered data. Cronbach alpha was used to test the reliability of the scale; it was found that alpha value for each variable was greater than accepted percent 0.60 which reflected the reliability of the scale.

Table 1. Cronbach alpha

\begin{tabular}{ll}
\hline IT Infrastructure & 0.918 \\
\hline Data Entry and Outcome & 0.896 \\
\hline Internal Operations & 0.865 \\
\hline Control procedures and tools & 0.877 \\
\hline Data Security & 0.853 \\
\hline Quality of Internal Auditing & 0.953 \\
\hline
\end{tabular}

\section{Analysis and Discussion}

\subsection{Demographics}

Following table (2) presented means and percentages of the two samples responses to questionnaire statements. The table showed that gender wise both samples presented the major responses for the benefit of males forming $75.2 \%$ in Jordan and $64.7 \%$ in UK which appeared high in both countries. As for age range, results also indicated that respondents within both sample scored the highest for individuals within age range of $37-42$ years old scoring a percentage of $33.1 \%$ and $36.0 \%$ for Jordan and UK respectively. Table also showed that regarding educational level, results also indicated that BA holders appeared to represent the majority of respondents scoring $48.9 \%$ and $54.7 \%$ for Jordan and UK respectively. Answering the experience demographic question revealed the same which indicated that majority of individuals within samples had an experience of +17 years of of working as internal auditing scoring $40.6 \%$ for Jordan and $42.0 \%$ for UK. 
Table 2. Crosstabs of Sample Characteristics According to Demographics

\section{Gender}

\begin{tabular}{|c|c|c|c|c|}
\hline & & Jordan & UK & Total \\
\hline \multirow[t]{2}{*}{ Male } & Count & 100 & 214 & 314 \\
\hline & \% within sample & $75.2 \%$ & $64.7 \%$ & $67.7 \%$ \\
\hline \multirow[t]{4}{*}{ Female } & Count & 33 & 117 & 150 \\
\hline & \% within sample & $24.8 \%$ & $35.3 \%$ & $32.3 \%$ \\
\hline & & & & \\
\hline & & Jordan & UK & Total \\
\hline \multirow[t]{2}{*}{$25-30$} & Count & 12 & 24 & 36 \\
\hline & $\%$ within sample & $9.0 \%$ & $7.3 \%$ & $7.8 \%$ \\
\hline \multirow[t]{2}{*}{$31-36$} & Count & 35 & 79 & 114 \\
\hline & $\%$ within sample & $26.3 \%$ & $23.9 \%$ & $24.6 \%$ \\
\hline \multirow[t]{2}{*}{$37-42$} & Count & 44 & 119 & 163 \\
\hline & $\%$ within sample & $33.1 \%$ & $36.0 \%$ & $35.1 \%$ \\
\hline \multirow[t]{2}{*}{+43} & Count & 42 & 109 & 151 \\
\hline & $\%$ within sample & $31.6 \%$ & $32.9 \%$ & $32.5 \%$ \\
\hline
\end{tabular}

\section{Educational Level}

\begin{tabular}{lllc|c|c} 
& & Jordan & UK & Total \\
\hline \multirow{2}{*}{ BA } & Count & 65 & 181 & 246 \\
\cline { 2 - 5 } & \% within sample & $\mathbf{4 8 . 9 \%}$ & $\mathbf{5 4 . 7 \%}$ & $53.0 \%$ \\
\hline \multirow{2}{*}{ MA } & Count & 50 & 114 & 164 \\
\cline { 2 - 5 } & \% within sample & $37.6 \%$ & $34.4 \%$ & $35.3 \%$ \\
\hline \multirow{2}{*}{ PhD } & Count & 18 & 36 & 54 \\
\cline { 2 - 5 } & \% within sample & $13.5 \%$ & $10.9 \%$ & $11.6 \%$
\end{tabular}

Experience

\begin{tabular}{lllc|c|c} 
& & Jordan & UK & Total \\
\hline $2-6$ & Count & 10 & 20 & 30 \\
\cline { 2 - 5 } & \% within sample & $7.5 \%$ & $6.0 \%$ & $6.5 \%$ \\
\hline \multirow{2}{*}{$7-11$} & Count & 21 & 45 & 66 \\
\hline & \% within sample & $15.8 \%$ & $13.6 \%$ & $14.2 \%$ \\
\hline \multirow{2}{*}{$12-16$} & Count & 48 & 127 & 175 \\
\hline & \% within sample & $36.1 \%$ & $38.4 \%$ & $37.7 \%$ \\
\hline \multirow{2}{*}{+17} & Count & 54 & 139 & 193 \\
\hline & \% within sample & $\mathbf{4 0 . 6 \%}$ & $\mathbf{4 2 . 0 \%}$ & $41.6 \%$
\end{tabular}

\subsection{Questionnaire Analysis}

Examining the following table (3) indicated responses of individuals to statements of study, as it can be seen individuals had positive attitudes for each and every statements noting that all means were above than mean of scale 3.00/5.00 which was seen as statistically significant. Looking deeper into the table, it can be noted that the highest mean for variables appeared to be within the variable of internal operations as it scored a mean of $(4.25 / 5.00)$ as the highest positively answered variable. It was followed directly by a mean of (4.04/5.00) for data security. This indicated that both samples in Jordan and UK have looked at internal operations and data security as the most apparent risks that would interfere with quality of 


\section{Table 3. Statements' Mean and Standard Deviation}

\section{Risks of Automated AIS Application}

\section{IT Infrastructure}

\begin{tabular}{lcc|c|c|c|c|c} 
& & $\mathrm{a} 1$ & $\mathrm{a} 2$ & $\mathrm{a} 3$ & $\mathrm{a} 4$ & $\mathrm{a} 5$ & $\mathrm{IT}$ \\
\hline Jordan & Mean & 3.76 & 3.92 & 3.70 & 3.95 & 3.78 & 3.8226 \\
\cline { 2 - 8 } & $\mathrm{N}$ & 133 & 133 & 133 & 133 & 133 & 133 \\
\cline { 2 - 8 } & $\begin{array}{c}\text { Std. } \\
\text { Deviation }\end{array}$ & 1.122 & 1.128 & 1.135 & 1.100 & 1.110 & .97379 \\
\hline UK & Mean & 3.88 & 4.01 & 3.80 & 4.04 & 3.88 & 3.9233 \\
\hline & $\mathrm{N}$ & 331 & 331 & 331 & 331 & 331 & 331 \\
\hline & $\begin{array}{c}\text { Std. } \\
\text { Deviation }\end{array}$ & 1.090 & 1.090 & 1.112 & 1.067 & 1.093 & .94428 \\
\hline Total & Mean & 3.85 & 3.98 & 3.77 & 4.02 & 3.85 & $\mathbf{3 . 8 9 4 4}$ \\
\hline & $\mathrm{N}$ & 464 & 464 & 464 & 464 & 464 & 464 \\
\hline & Std. & 1.100 & 1.101 & 1.119 & 1.076 & 1.098 & .95287 \\
\hline & Deviation & & & & & & \\
\hline
\end{tabular}

Data Entry and Outcome

\begin{tabular}{lc|c|c|c|c|c|c} 
sample & & $\mathrm{b} 6$ & $\mathrm{~b} 7$ & $\mathrm{~b} 8$ & $\mathrm{~b} 9$ & $\mathrm{~b} 10$ & Outcome \\
\hline Jordan & Mean & 4.23 & 3.96 & 4.16 & 4.13 & 4.01 & 4.0962 \\
\cline { 2 - 8 } & $\mathrm{N}$ & 133 & 133 & 133 & 133 & 133 & 133 \\
\cline { 2 - 8 } & $\begin{array}{c}\text { Std. } \\
\text { Deviation }\end{array}$ & .804 & .965 & .737 & .900 & .754 & .69831 \\
\hline UK & Mean & 4.29 & 4.02 & 4.23 & 4.19 & 4.10 & 4.1656 \\
\hline & $\mathrm{N}$ & 331 & 331 & 331 & 331 & 331 & 331 \\
\hline & $\begin{array}{c}\text { Std. } \\
\text { Deviation }\end{array}$ & .790 & .994 & .736 & .915 & .765 & .71259 \\
\hline Total & Mean & 4.27 & 4.01 & 4.21 & 4.17 & 4.07 & $\mathbf{4 . 1 4 5 7}$ \\
\hline & $\mathrm{N}$ & 464 & 464 & 464 & 464 & 464 & 464 \\
\hline & $\begin{array}{c}\text { Std. } \\
\text { Deviation }\end{array}$ & .794 & .985 & .736 & .910 & .762 & .70847 \\
\hline
\end{tabular}

Source: Appendix 1

\section{Internal Operations}

sample

\begin{tabular}{lc|c|c|c|c|c|c|c|c}
\hline Jordan & Mean & 4.32 & 4.33 & 4.20 & 4.33 & 3.84 & 4.20 & 4.2043 \\
\cline { 2 - 10 } & $\mathrm{N}$ & 133 & 133 & 133 & 133 & 133 & 133 & 133 \\
\cline { 2 - 10 } & $\begin{array}{c}\text { Std. } \\
\text { Deviation }\end{array}$ & .689 & .704 & .660 & .746 & .991 & .886 & .59551 \\
\hline UK & Mean & 4.36 & 4.38 & 4.25 & 4.38 & 3.95 & 4.28 & 4.2694 \\
\hline & $\mathrm{N}$ & 331 & 331 & 331 & 331 & 331 & 331 & 331 \\
\hline & $\begin{array}{c}\text { Std. } \\
\text { Deviation }\end{array}$ & .684 & .696 & .662 & .751 & .991 & .852 & .60901 \\
\hline Total & Mean & 4.35 & 4.37 & 4.24 & 4.37 & 3.92 & 4.26 & $\mathbf{4 . 2 5 0 7}$ \\
\hline & $\mathrm{N}$ & 464 & 464 & 464 & 464 & 464 & 464 & 464 \\
\hline
\end{tabular}




\begin{tabular}{l|c|c|c|c|c|c|c|c}
\hline & $\begin{array}{c}\text { Std. } \\
\text { Deviation }\end{array}$ & .685 & .698 & .661 & .749 & .992 & .861 & .60525 \\
\hline Source: Appendix 1
\end{tabular}

Control procedures and tools

\begin{tabular}{|c|c|c|c|c|c|c|c|c|c|}
\hline sample & & & & $\mathrm{d} 17$ & $\mathrm{~d} 18$ & d19 & $\mathrm{d} 20$ & $\mathrm{~d} 21$ & Control \\
\hline \multirow[t]{3}{*}{ Jordan } & Mean & 3.93 & 3.90 & 3.87 & 4.28 & 3.92 & 3.9805 & & \\
\hline & $\mathrm{N}$ & 133 & 133 & 133 & 133 & 133 & 133 & & \\
\hline & $\begin{array}{c}\text { Std. } \\
\text { Deviation }\end{array}$ & 1.016 & 1.036 & .856 & .667 & .729 & .70533 & & \\
\hline \multirow[t]{3}{*}{ UK } & & & Mean & 4.04 & 3.98 & 3.96 & 4.34 & 3.98 & 4.0604 \\
\hline & & & $\mathrm{N}$ & 331 & 331 & 331 & 331 & 331 & 331 \\
\hline & & & $\begin{array}{c}\text { Std. } \\
\text { Deviation }\end{array}$ & .989 & 1.030 & .863 & .683 & .760 & .71991 \\
\hline \multirow[t]{3}{*}{ Total } & & & Mean & 4.01 & 3.96 & 3.94 & 4.32 & 3.96 & 4.0375 \\
\hline & & & $\mathrm{N}$ & 464 & 464 & 464 & 464 & 464 & 464 \\
\hline & & & $\begin{array}{c}\text { Std. } \\
\text { Deviation }\end{array}$ & .997 & 1.031 & .861 & .679 & .751 & .71592 \\
\hline
\end{tabular}

\section{Data Security}

\begin{tabular}{lcc|c|c|c|c|c} 
sample & & $\mathrm{e} 22$ & $\mathrm{e} 23$ & $\mathrm{e} 24$ & $\mathrm{e} 25$ & $\mathrm{e} 26$ & Security \\
\hline Jordan & Mean & 3.92 & 3.99 & 3.99 & 3.62 & 3.76 & 3.8571 \\
\cline { 2 - 8 } & $\mathrm{N}$ & 133 & 133 & 133 & 133 & 133 & 133 \\
\cline { 2 - 8 } & $\begin{array}{c}\text { Std. } \\
\text { Deviation }\end{array}$ & 1.080 & 1.145 & 1.048 & 1.312 & 1.327 & 1.00320 \\
\hline UK & Mean & 4.17 & 4.25 & 4.27 & 3.92 & 4.02 & 4.1239 \\
\hline & $\mathrm{N}$ & 331 & 331 & 331 & 331 & 331 & 331 \\
\cline { 2 - 8 } & $\begin{array}{c}\text { Std. } \\
\text { Deviation }\end{array}$ & .835 & .870 & .724 & 1.099 & 1.095 & .70548 \\
\hline Total & Mean & 4.09 & 4.17 & 4.19 & 3.83 & 3.94 & $\mathbf{4 . 0 4 7 4}$ \\
\hline & $\mathrm{N}$ & 464 & 464 & 464 & 464 & 464 & 464 \\
\hline & $\begin{array}{c}\text { Std. } \\
\text { Deviation }\end{array}$ & .918 & .962 & .838 & 1.170 & 1.171 & .81008 \\
\hline
\end{tabular}

Source: Appendix 1

\section{Quality of Internal Auditing}

\begin{tabular}{|c|c|c|c|c|c|c|c|c|}
\hline sample & & $\mathrm{f} 27$ & $\mathrm{f} 28$ & $\mathrm{f} 29$ & $\mathrm{f} 30$ & $\mathrm{f} 31$ & $\mathrm{f} 32$ & Quality \\
\hline \multirow[t]{3}{*}{ Jordan } & Mean & 2.98 & 3.14 & 3.04 & 3.41 & 3.23 & 3.35 & 3.1917 \\
\hline & $\mathrm{N}$ & 133 & 133 & 133 & 133 & 133 & 133 & 133 \\
\hline & $\begin{array}{c}\text { Std. } \\
\text { Deviation }\end{array}$ & 1.586 & 1.648 & 1.602 & 1.606 & 1.560 & 1.557 & 1.51292 \\
\hline \multirow[t]{3}{*}{ UK } & Mean & 3.83 & 4.07 & 3.92 & 4.33 & 4.06 & 4.27 & 4.0775 \\
\hline & $\mathrm{N}$ & 331 & 331 & 331 & 331 & 331 & 331 & 331 \\
\hline & $\begin{array}{c}\text { Std. } \\
\text { Deviation }\end{array}$ & 1.127 & 1.077 & 1.102 & .799 & 1.010 & .748 & .81082 \\
\hline \multirow[t]{3}{*}{ Total } & Mean & 3.59 & 3.80 & 3.67 & 4.06 & 3.82 & 4.00 & 3.8236 \\
\hline & $\mathrm{N}$ & 464 & 464 & 464 & 464 & 464 & 464 & 464 \\
\hline & $\begin{array}{c}\text { Std. } \\
\text { Deviation }\end{array}$ & 1.330 & 1.332 & 1.325 & 1.167 & 1.251 & 1.124 & 1.13223 \\
\hline
\end{tabular}




\subsection{Multicollinearity Test}

Multicollinearity test was used to ensure that there was no problem of multiple linear correlation between variables using VIF, tolerance, taking into account a VIF value greater than 10 and tolerance value greater than 0.10 (Hair et al, 2012). Based on results of analysis, VIF value was less than 10 whereas tolerance value was greater than 0.10 , this meant that - as in table 4 - there were no multicolleniarity.

\section{Table 4. Collinearity Statistics}

\begin{tabular}{l|l|l} 
Model & Tolerance & VIF \\
\cline { 2 - 3 } IT Infrastructure & .285 & 3.512 \\
\hline Data Entry and Outcome & .303 & 3.302 \\
\hline Internal Operations & .198 & 5.041 \\
\hline Control procedures and tools & .137 & 7.274 \\
\hline Data Security & .305 & 3.278 \\
\hline
\end{tabular}

\subsection{Hypotheses Testing}

\section{Main Hypothesis}

H1: Risks of Automated AIS Application has the ability to increase the Quality of Internal Auditing

Table 5. Testing $\mathrm{H}_{1}$

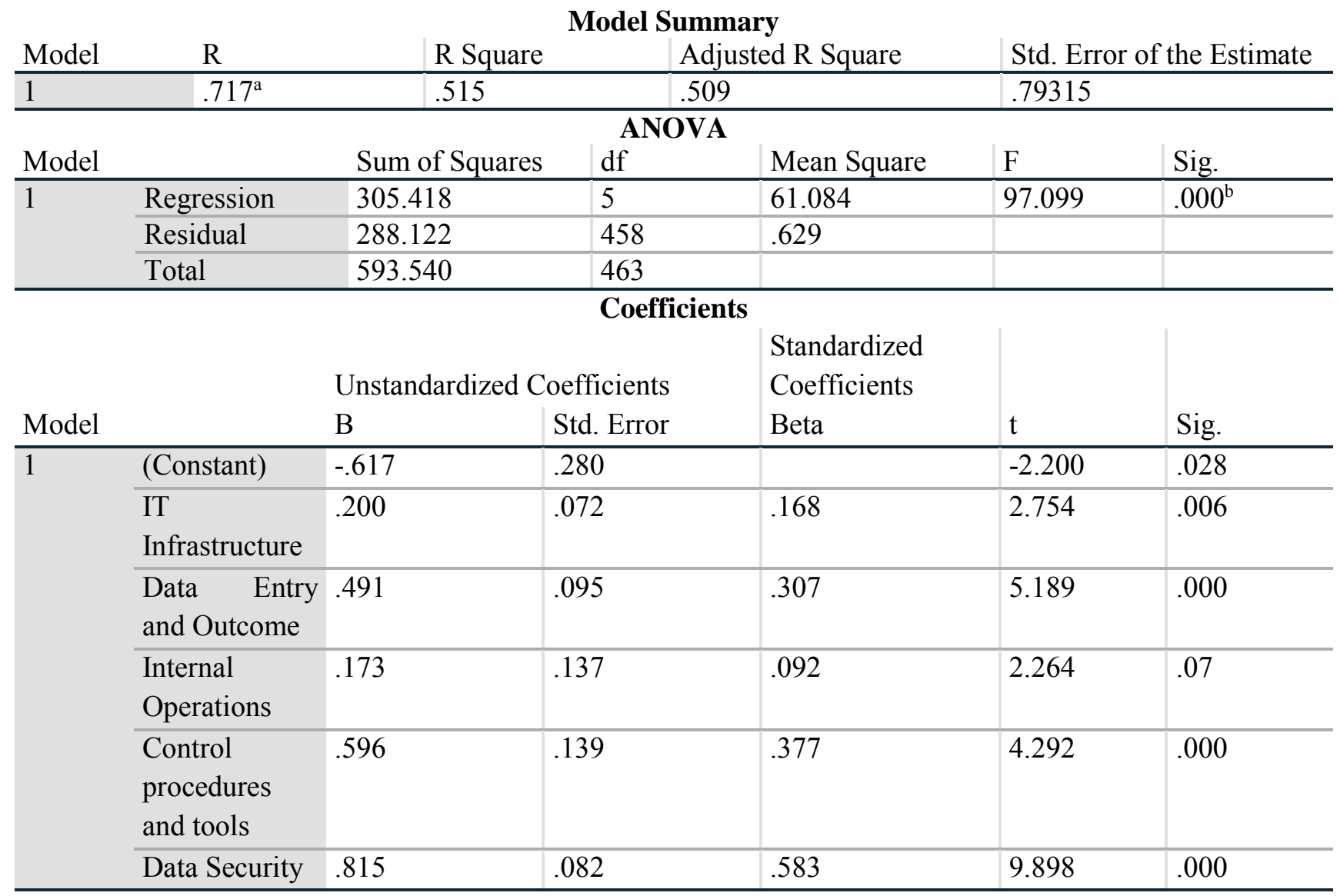

Multiple regression was used to test above hypothesis, $r=0.717$ reflected high and positive relationship between the independent variables and the dependent variable. Also, it was found that the independent variables explained $51.5 \%$ in the variance of the dependent variable. Also it was 
found that $\mathrm{F}$ value was significant at 0.05 levels that meant Risks of Automated AIS Application has the ability to increase the Quality of Internal Auditing. Also it was found that $t$ value for each independent variable is significant at 0.05 level that means:

- IT Infrastructure has the ability to increase the Quality of Internal Auditing

- Data Entry and Outcome has the ability to increase the Quality of Internal Auditing

- Internal Operations has the ability to increase the Quality of Internal Auditing

- Control procedures and tools has the ability to increase the Quality of Internal Auditing

- Data Security has the ability to increase the Quality of Internal Auditing

H2: The impact of Risks of Automated AIS Application on increasing Quality of Internal Auditing differs between Jordan and United Kingdom

\section{Table 6. Testing $\mathrm{H}_{2}$}

\section{Tests of Between-Subjects Effects}

Dependent Variable: Quality

\begin{tabular}{ll|l|l|l|l} 
Source & Squares & df & Mean Square & F & Sig. \\
\hline Corrected Model & $386.001^{\mathrm{a}}$ & 57 & 6.772 & 13.248 & .000 \\
\hline Intercept & 2255.173 & 1 & 2255.173 & 4411.702 & .000 \\
\hline Risks of Automated AIS Application & 221.100 & 30 & 7.370 & $\mathbf{1 4 . 4 1 8}$ & .000 \\
\hline sample & 30.757 & 1 & 30.757 & 60.169 & .000 \\
\hline $\begin{array}{l}\text { Risks of Automated AIS Application } \\
\text { sample }\end{array}$ & 31.959 & 26 & 1.229 & 2.405 & .000 \\
\hline $\begin{array}{l}\text { Error } \\
\text { Total }\end{array}$ & 207.539 & 406 & .511 & & \\
\hline Corrected Total & 7377.306 & 464 & & & \\
\hline
\end{tabular}

a. R Squared $=.650$ (Adjusted R Squared $=.601)$

2 way ANOVA was used to test above hypothesis.

Above table showed that $\mathrm{F}$ value $=14.418$ was significant at 0.05 level that meant Risks of Automated AIS Application has an effect of quality of internal auditing, also $F$ value $=60.169$ was significant at 0.05 level, that meant quality of internal auditing differs between the two samples. Above table shows also that $F=2.405$ was significant at 0.05 level, that meant the impact of
Risks of Automated AIS Application on increasing Quality of Internal Auditing differs between Jordan and United Kingdom.

This difference tended to increase in UK sample since its mean $=4.09$ were greater than Jordan sample as shown in the following table:

Table 6. Estimated Marginal Means

1. sample

Dependent Variable: Quality

\begin{tabular}{|c|c|c|c|c|}
\hline sample & Mean & Std. Error & $\begin{array}{l}95 \% \text { Confidence Interval } \\
\text { Lower Bound }\end{array}$ & Upper Bound \\
\hline Jordan & 3.046 & .083 & 2.883 & 3.208 \\
\hline UK & $4.090^{\mathrm{a}}$ & .051 & 3.990 & 4.189 \\
\hline
\end{tabular}

a. Based on modified population marginal mean. 


\subsection{Discussion}

Current study aimed at evaluating the influence of automated AIS applications on quality of internal auditing. Quantitative approach was employed and a questionnaire was utilized to resemble the tool of study. Population consisted of internal auditors from different auditing offices in both Jordan and UK. A convenient sample was chosen from Jordan which consisted of (133) internal auditors and UK consisting of (331) internal auditors. AMOS was used in order to tackle, screen, process and analyze gathered data from both countries. Results indicated that the main hypothesis was accepted and there appeared an influence on automated AIS applications on quality of internal auditing that is attributed to risks including (IT Infrastructure, Data Entry and Outcome, Internal Operations, Control procedures and tools and Data Security).

\section{Risks of Automated AIS Application has the ability to increase the Quality of Internal Auditing}

Analyzing the gathered data in accordance with respondents' orientations and answers indicated that the first hypothesis was accepted, and there are risks within automated AIS applications that would jeopardize the quality of internal auditing. As the analysis showed before, the most significant variables of automated AIS applications appeared to be for internal operations which scored a significance level of 0.07. Based on that, it can be said that the main hypothesis is supported and automated AIS applications are helpful in terms of supporting quality of internal auditing in terms of better use of internal resources, matching required standards of auditing, and present outcomes that explains the reality of financial status of the organization. This was agreed on by [4] and [1] who argued that internal operation are extremely critical if the organization aimed at achieving a high quality internal auditing, this means that the organization has to make sure that all resource, data and information are used in an effective way that ensures a well-built internal auditing.
The impact of Risks of Automated AIS Application on increasing Quality of Internal Auditing differs between Jordan and United Kingdom

The study proved, like many previous studies including [14]; [6]; [42]; [33]; [2]; [46] that AIS are considered less safe than manual systems, especially in internal auditing and its results, and these risks stem from the adoption of computerized accounting information systems to save data in electronic files that are subject to damage or loss or even the possibility of a number A large number of people can access it and see it. Same results appeared with [23]; [43] and [27] who argued that the level of fragility within automated AIS is much less than the fragility within automated AIS, this makes automated AIS exposed to higher level of risks associated with piracy, unauthorized usage and manipulation. It was indicated through results of study that there are many risks within automated AIS applications that may play a role in jeopardizing the quality of internal auditing, such risks are predictable given that such application have a high dependency level on internet, and it is widely understandable that such dependency makes applications more vulnerable to piracy and hacking incidents which in its turn may form a big risk on data and information stored within such applications. [26] seemed to agree with this result arguing that results and reports of the internal audit imply the necessity to provide accurate, correct and with a high degree of reliability in order to provide a summary consistent with the actual reality of the organization, this also agreed with [30] arguing that the internal audit is closely related to the validity of the information entered and any change in this information or Its content could harm the organization and its property, as well as providing false information and fraudulent violations related to the electronic systems used.

\section{The Comparison Account}

Returning to the different location of the study sample that was dealt with, the idea was reached that the risks between Jordan and England are actually similar in terms of the idea that the total 
reliance on automated programs is based on many risks that the organization must accept as it is, but at the time. Himself adopts strategies and plans in order to deal with it. The difference between the samples taken in the current study between Jordan and England lies in the difference in the size of the sample, and this matter seems natural because the sample of England is larger than the sample of Jordan. Consequently, it can be said that the risks of using automated AIS differ between Jordan and England due to the different nature of internal operations in them, in addition to the fact that England is larger and higher in population than Jordan, and therefore it is natural that the risks will be more extensive due to the huge size of internal auditing in England compared to Jordan. This managed to effect results of study in terms of aspects that are related to country size, population and level of operations within the auditing field. As it is widely known England is a larger country than Jordan, it is stretched on $130,279 \mathrm{~km}^{2}$ and populated of 55.98 million compared to Jordan which is stretched on a space of $89,342 \mathrm{~km}$ and populated of 10.1 million. Not to mention the nature of operations and size of organizations working within the country given the fact that GDP of England is \$2.64 trillion while Jordan's GDP is $\$ 39.00$ USD. Another comparison between two samples appeared in terms of variables. As it was mentioned before, risks of automated AIS applications were listed, and there appeared a difference between Jordan and England in terms of data security and IT infrastructure. The study indicated that the standards and characteristics of data security and IT infrastructure were stronger in England compared to Jordan, and therefore the risks - despite the exposure of both countries to them - appeared to be less in terms of negative impact on England compared to Jordan, where in England the two variables (data security and IT infrastructure) scored a mean that is higher than Jordan in positivity given that data security scored a mean of 4.12/5.00 and IT infrastructure scored $3.92 / 5.00$.

\section{Conclusion and Recommendations}

Internal auditing is an independent, objective guarantee and consulting activity that aims to add value to and improve the organization's operations. It helps in achieving the organization's objectives by adopting a systematic and structured approach to evaluate and improve the effectiveness of governance, risk management and control. It also aims to help members of the organization carry out their responsibilities effectively. To this end, this audit provides them with analysis, evaluations, recommendations, advice and information related to the activities under review. The study showed the importance of internal auditors 'awareness of the need to keep pace with modern technological developments in the performance of their accounting tasks, and at the same time an actual awareness of the nature of the risks involved in relying on technology in accounting work, in addition to the perception of the idea that accounting work, specifically internal auditing, implies the importance of having relevant outputs. High accuracy, reliability and quality as well as low cost. Here, the importance of being aware of the risks of technology and its vulnerability to piracy and cyber-attacks, which would harm the interests of the organization by negatively affecting the outputs of the internal audit. Therefore, the total reliance on automated AIS applications involves many risks that would affect the quality of internal audit, and organizations are required to conduct many general tests of mental capabilities and technical knowledge tests in the field of eaccounting, these tests include identifying the internal auditor in the sequencing system of letters and numbers, and identifying the auditor's ability to solve algebraic equations, ability or speed to enter accounting data, ability to prepare flow maps and deduction from reality and the ability to analyze and think logically. Such tests can be attained through focusing on auditors approaches in dealing with AIS applications, their expertise and ability to work will with such systems, in addition to that, in current research it was highlighted that individuals showed high level of awareness regarding the variable of AIS applications and its risks as their answers were tested and showed a high level of 
understanding, this appeared through the consistency of the study tool and the homogenous results which were reached through the analysis. However, there must be a space were more enhancement and development should be given to auditors in the field of employing AIS applications within the auditing process.

Based on results and conclusion, current study recommended:

- The management of the organization is required to protect its data, especially nonpaper, by all available advanced means

- Putting restrictions on users to limit the possibility of changing and manipulating the data, whether by parties inside or outside the organization

Organizations should focus on accountants passing the legal accounting tests or management accounting tests, because they are more qualified to fill accounting jobs and with regard to computers that can be used in some accounting applications

\section{References}

[1]. Abdullatif, M., \& Kawuq, S. (2015). The role of internal auditing in risk management: evidence from banks in Jordan. Journal of Economic and Administrative Sciences.

[2]. Abu-Musa, A. A. (2004). Important Threats to Computerized Accounting Information Systems: An empirical Study on Saudi Organizations. Pubic Administration, A Professional Quarterly Journal Published by The Institute of Public Administration Riyadh, Saudi Arabia, 44(3), 1-65.

[3]. Adamyk, O. (2017). Audit of Accounting Staff in Computer-Based Environment, national vision and globalization challenges: Collection of scientific articles / ISBN 978-0-692-875896. - P. 152-153.

[4]. Al-Akra, M., Abdel-Qader, W., \& Billah, M. (2016). Internal auditing in the Middle East and North Africa: A literature review. Journal of
International Accounting, Auditing and Taxation, 26, 13-27.

[5]. Al-Baheisi, E and Al-Shareef, H. (2008). The risks of electronic accounting information systems: an applied study on the banks operating in the Gaza Strip. IUG Journal of Humanities Research, 16(2), 895-923

[6]. Ali, O. H. (2020). The Role of the Mechanisms of Information Technology Governance in Activating the Risk Management of Computerized Accounting Information Systems According to (NIST800-37) Framework of Internal Control: An analytical Study of a Sample of Joint Stock Companies and Auditors in the Kurdistan Region of Iraq for 2019. Qalaai Zanist Journal, 5(3), 498-531.

[7]. Al-Obaidi, F. (2012). The Risk of Using Computerized Accounting Information Systems and its Impact on the Efficiency of Auditing Process in Jordan, MA Thesis, Middle East University, Amman - Jordan

[8]. Al-Shbail, A. M., \& Turki, A. A. (2017). A theoretical discussion of internal audit effectiveness in Kuwaiti industrial SMEs. International Journal of Academic Research in Accounting, Finance and Management Sciences, 7(1), 107-116.

[9]. Al-Wattar, Y. M. A., Almagtome, A. H., \& AL-Shafeay, K. M. (2019). The role of integrating hotel sustainability reporting practices into an Accounting Information System to enhance Hotel Financial Performance: Evidence from Iraq. African Journal of Hospitality, Tourism and Leisure, 8(5), 1-16.

[10]. Alzeban, A. (2015). The impact of culture on the quality of internal audit: An empirical study. Journal of Accounting, Auditing \& Finance, 30(1), 57-77.

[11]. Arif, D., Yucha, N., Setiawan, S., Oktarina, D., \& Martah, V. (2020). Applications of goods mutation control form in accounting information system: A case study in sumber indah perkasa manufacturing, Indonesia. Journal of Asian Finance, Economics and Business, 7(8), 419-424.

[12]. Axmedjanov, K. (2020). KB Akhmedjanov INTERNAL AUDIT AND ITS 


\section{DEVELOPMENT}

PROSPECTS. Архив

научных исследований, 1(4).

[13]. Azmi, F., \& Sri, M. (2020). Factors that affect accounting information system success and its implication on accounting information quality. SIMILIARITY.

[14]. Bansah, E. A. (2018). The threats of using computerized accounting information systems in the banking industry. Journal of Accounting and Management Information Systems, 18(3), 440-461.

[15]. Dai, J., \& Vasarhelyi, M. A. (2017). Toward blockchain-based accounting and assurance. Journal of Information Systems, 31(3), 5-21.

[16]. Dewi, I. G. A. A. O., Dewi, I. G. A. A. P., Kustina, K. T., \& Prena, G. D. (2018). Culture of tri hita karana on ease of use perception and use of accounting information system. International journal of social sciences and humanities, 2(2), 77-86.

[17]. Elbardan, H., \& Kholeif, A. (2017). Enterprise resource planning, corporate governance and internal auditing. Springer Books.

[18]. Endaya, K. A., \& Hanefah, M. M. (2016). Internal auditor characteristics, internal audit effectiveness, and moderating effect of senior management. Journal of Economic and Administrative Sciences.

[19]. Ferri, P., Lusiani, M., \& Pareschi, L. (2018). Accounting for Accounting History: A topic modeling approach (19962015). Accounting History, 23(1-2), 173-205.

[20]. Fülöp, M. T., \& Szekely, S. V. (2017). The evolution of the internal auditing function in the context of corporate transparency. The Audit Financiar journal, 15(147), 440-440.

[21]. Garven, S., \& Scarlata, A. (2020). An examination of factors associated with investment in internal auditing technology. Managerial Auditing Journal, 35(7), 955-978.

[22]. Huerta, E., \& Jensen, S. (2017). An accounting information systems perspective on data analytics and Big Data. Journal of Information Systems, 31(3), 101-114.
[23]. Isa, A. (2017). The impact of computerized accounting information system on management performance in public sector in Nigeria: Problems and prospects. International Journal of Multidisciplinary Research and Development, 4(12), 80-83.

[24]. Kewo, C. L., \& Afiah, N. N. (2017). Does Quality of Financial Statement Affected by Internal Control System and Internal Audit?. International Journal of Economics and Financial Issues, 7(2), 568.

[25]. Lai, A., \& Samkin, G. (2017). Accounting history in diverse settings-an introduction. Accounting History., 22(3), 265-273.

[26]. Loch, K. D., Carr, H. H., \& Warkentin, M. E. (1992). Threats to information systems: today's reality, yesterday's understanding. Mis Quarterly, 173-186.

[27]. Lutui, R., \& Ahokovi, T. A. (2018). The relevance of a good internal control system in a computerised accounting information system, In proceedings of the 16th Australian Information Security Management Conference (pp. 29-40). Perth, Australia: Edith Cowan University.

[28]. Mansor, M. (2018). Integrated internal audit model for effective internal auditing performance in Nigerian tax administration. Asian Journal of Economics, Business and Accounting, 1-7.

[29]. Mat Zain, M., Zaman, M., \& Mohamed, Z. (2015). The effect of internal audit function quality and internal audit contribution to external audit on audit fees. International Journal of Auditing, 19(3), 134-147.

[30]. Mbilla, S. A. E., Nyeadi, J. D., Akolgo, D. A., \& Abiire, M. A. (2020). Impact of Computerized Accounting Systems on the Quality of Financial Reports in the Banking Sector of Ghana, European Journal of Business and Management, 12(17)

[31]. Mexmonov, S. (2020). The Role of the Internal Audit Based International Internal Audit Standards in Uzbekistan. Архив научных исследований, 33(1).

[32]. Mihret, D. G., \& Grant, B. (2017). The role of internal auditing in corporate governance: a 
Foucauldian analysis. Accounting, Auditing \& Accountability Journal, 30(3), 699-719

[33]. Mohammed, A. L., Al-Hosban, A., \& Thnaibat, H. (2018). The impact of the risks of the input of accounting information systems on managerial control, accounting control and internal control in commercial banks in Jordan. International Journal of Business and Management, 13(2), 96-107.

[34]. Parker, S., \& Johnson, L. A. (2017). The development of internal auditing as a profession in the US during the twentieth century. Accounting Historians Journal, 44(2), 47-67.

[35]. Paulsson, V. (2017). Development of accounting information systems over time. In The Routledge companion to accounting information systems (pp. 13-23). Routledge.

[36]. Rashedi, H., \& Dargahi, T. (2019). How Influence the Accounting Information Systems Quality of Internal Control On Financial Reporting Quality. JMDMA, 2(5), 33-45.

[37]. Rudd, M. B., Thorson, J. T., \& Sagarese, S. R. (2019). Ensemble models for data-poor assessment: accounting for uncertainty in lifehistory information. ICES Journal of Marine Science, 76(4), 870-883.

[38]. Sari, N. Z., SE, M., \& Purwanegara, H. D. (2016). The Effect of Quality Accounting Information System Indonesian Goverment (BUMD) at bandung area. Research Journal of Finance and Accounting.

[39]. Sinha, V. K., \& Arena, M. (2020). Manifold conceptions of the internal auditing of risk culture in the financial sector. Journal of Business Ethics, 162(1), 81-102.

[40]. Spraakman, G. P., \& Quinn, M. (2018). Accounting history research topics-An analysis of leading journals, 20062015. Accounting Historians Journal, 45(1), 101-114.

[41]. Tan, O. (2016). Impact of accounting information systems on internal auditors in Turkey. Marmara Üniversitesi Öneri Dergisi, 12.

[42]. Tarmidi, M., Rashid, A. A., \& Abdullah, W. M. T. W. (2017). An analysis of computerized accounting system security threats in Malaysian public listed companies. Terengganu International Finance and Economics Journal (TIFEJ), 2(1), 28-35.

[43]. Topcu, A. G. G. (2019). Impact of Accounting Information System (AIS) on Fraud Detection. Management and Political Sciences Review, 1(1), 81-92.

[44]. Trinandha, A., \& Ghozali, I. (2018). Understanding the Potential Impact of Accounting Information System to Computer Accounting Fraud, International Journal of Engineering Research and Technology, 11(2)

[45]. Uyar, A., Gungormus, A. H., \& Kuzey, C. (2017). Impact of the accounting information system on corporate governance: Evidence from Turkish non-listed companies. Australasian Accounting, Business and Finance Journal, 11(1), 9-27.

[46]. Uzrail, A. H., \& Bardai, B. (2019). Moderating Effect of the Adoption of Computerized Accounting Information Systems and the Perceived Effect on Financial Performance-A Study of Palestinian Companies Case. International Journal of All Research Writings, 2(2), 63-74.

[47]. Волот, О. І., \& Росохач, О. В. (2016). Features of modern automated accounting information system and their using in USA companies, Problems and prospects of economics and management, 4 (8), 199-204.

[48]. Nursel Selver Ruzgar, Clare Chua, Data Level Approach for Multiclass Imbalance Financial Data, WSEAS Transactions on Computers, ISSN / E-ISSN: 1109-2750 / 22242872, Volume 19, 2020, Art. \#22, pp. 165-182.

[49]. Valbona Cinaj, Manuela Me?e, Artur Ribaj, Ilda Kadrimi, The Need for Improvement of External Audit Reports of Banks (The Case of Banks in Albania which Mainly belong to EU Banks), WSEAS Transactions on Environment and Development, ISSN / E-ISSN: 1790-5079 / 2224-3496, Volume 16, 2020, Art. \#55, pp. 539-547.

Creative Commons Attribution License 4.0 (Attribution 4.0 International, CC BY 4.0)

This article is published under the terms of the Creative Commons Attribution License 4.0

https://creativecommons.org/licenses/by/4.0/deed.en_US 